\title{
Simulation of Scots pine stand dynamics under climate change conditions in the Polish and Ukrainian parts of Roztocze
}

\author{
Ihor Kozak ${ }^{\bowtie}$, Patrycja Czekajska, Hanna Kozak, Adam Stępień, Piotr Kociuba
}

The John Paul II Catholic University of Lublin, Department of Landscape Ecology, ul. Konstantynów 1H, 20-708 Lublin, Poland.

$$
\checkmark \text { Tel. + } 4881 \text { 4454531, e-mail: modeliho@kul.lublin.pl }
$$

\begin{abstract}
The study was conducted in the Polish (Roztoczanski National Park) and Ukrainian (Rava-Rus'ka Landscape Reserve and Yavorivskyi National Park) parts of the Roztocze region. In each of these locations three research areas were established in Scots pine (Pinus sylvestris L.) stands under similar ecological conditions. The purpose of this study was to carry out a survey of possible scenarios for pine stand dynamics in the Polish and Ukrainian parts of Roztocze using the FORKOME model. A control scenario was compared with four other climate change scenarios (warm dry and warm humid; cold dry and cold humid) for a period of covering the next 100 years. Using the control scenario, the FORKOME model predicted that for the next 100 years pine stands will dominate in terms of biomass and number of trees. The warm-dry and warm-humid climate scenarios resulted in slightly reduced biomass of pine stands. However pine would still maintain its dominance, although with a noticeable increase in beech and fir biomass. Nevertheless, in term of the number of trees during the second half of the simulation, it is beech and fir that dominate stand 1 in Roztoczanski National Park. Under the climate cooling scenario (cold dry and cold humid), the biomass of pine and spruce would increase during the next 100 years. Pine trees that would dominate in terms of their numbers, although the number of spruce individuals also tends to increase. The results presented in the paper indicate that the FORKOME model is very useful when investigating different climate changes scenarios in the Roztocze region.
\end{abstract}

Key words: Scots pine, beech, fir, spruce, FORKOME computer model, Roztocze, prognosis

\section{Introduction}

Dynamics of changes in pine stands and defining their directions regarding possible climate change conditions in Roztocze are important issues in forest management, both from the theoretical and practical point of view.

There is lack of data in literature regarding computer simulation of the dynamics of pine stands in Roztocze. Studies focusing on general analyses of pine stands mention that the area of Leucobryo-Pinetum decreases as a result of intensive increase in the number of beech and fir. Moreover, many substitute forest communities were formed as a result of previous forest management geared towards pine production (Izdebski et al. 1992).
In addition, progressing eutrophication of forest stands causes decreasing of Leucobryo-Pinetum communities and increasing range of mixed forest (Izdebski et al. 1992).

Other studies (Maciejewski 2009) confirm increasing deciduous species at the cost of decreasing coniferous species in the Roztoczański Narodowy Park (Roztoczanski National Park - RNP).

Catastrophic weather phenomena, for example frost and drought, wind-fallen trees, snow-fallen trees, and anthropogenic factors, are some of the reasons of the aforementioned changes.

Significant influence of climate fluctuation and industrial pollution may be noticed. It directly and indirectly influences eutrophication of forest habitats, 
and enables expansion of termophilic species (beech, fir) that intensively are shading the soil. It is important to test future dynamics of pine stands regarding climate changes, especially to test prognosis of pine and other species which share the forest stands by applying computer modelling.

The FORKOME model (Kozak et al. 2012) was applied to predict changes of pine stands. The model is similar to the JABOWA model (Botkin et al. 1972), FORET model (Shugart 1984) and the FORLAS model (Brzeziecki, Zajączkowski 2006).

The aim of the study was to carry out prognosis of possible changes of pine stands in Polish and Ukrainian parts of Roztocze during the next 100 years. Different scenarios of changes were included: a control scenario, warm-dry climate and warm-humid climate, colddry climate and cold-humid climate. We carried out a simulation of dynamics of pine stands with the use of FORKOME model on the basis of 3 research areas of pine stands grown on podzol soil. Influence of climate change conditions (changes of total effective temperatures and yearly total precipitation), decreasing process of pine and rebuilding of other species in this place (beech, fir, spruce, and hornbeam). Climate scenarios were to verify a thesis of pine maintained on researched areas in Roztocze under climate change variants. Aggregation of climate factors approach (Kahn 1994) was included in the analyses.

\section{Materials and methods}

The described research was performed between 2009 and 2011 in the Roztoczanski National Park, Poland (RNP), in the Poland and also in the Yavorivskyi National Park, Ukraine.

Three research areas were established at each of the aforementioned locations in forests with similar ecological conditions.

One research area from each location was selected for presentation herein. Proper podzol soils, poor in minerals prevail at all the locations with the LeucobryoPinetum plant community, which is the most common type of forest association in the whole Roztocze region. Forest stands characterised by similar species composition (10 pine + beech, fir, spruce) and age (one birch which vanished in the first years of prognosis was observed in the first area) prevailed in all research areas. The research areas were located in different parts of the Roztocze region. The first plot - 'Pine 1' is located in the forest district no. $189 \mathrm{f}$ in the Roztoczanski National Park $\left(50^{\circ} 36^{\prime} \mathrm{N}, 22^{\circ} 57^{\prime} \mathrm{E}\right)$, Poland, the second plot 'Pine $2^{\prime}$ ' is in the forest district no. 66/3, in the Rava-Rus'ka Landscape Reserve ( $\left.50^{\circ} 13^{\prime} \mathrm{N}, 23^{\circ} 37^{\prime} \mathrm{E}\right)$, Ukraine, while the third plot 'Pine 3' - is in the forest district no. 28/12, Mlynkivskyi forest range of the Yavorivskyi National Park, Ukraine ( $\left.50^{\circ} 03^{\prime} \mathrm{N}, 23^{\circ} 49^{\prime} \mathrm{E}\right)$.

Scots pine (Pinus sylvestris L.) dominated and common beech (Fagus sylvatica L.), fir (Abies alba Mill.) as well as Norway spruce (Picea abies L. Karst.) were present in all the areas. Canopy cover in layer A did not exceed $70-80 \%$. Due to the death of one or a few larger Scots pines, the cover was not distributed evenly. Groundcover consisted predominantly of common bilberry (Vaccinium myrtillus L.), grasses and, locally, mosses.

Pine, the prevailing tree species, grew in dry habitats and formed sunny and bright stands. Spruce, beech and fir were present in the bush layer. For pine, the mean DBH (see Table 1) for the plot 'Pine 1' $-24,4 \mathrm{~cm}$ (max $65, \min 5)$, for 'Pine 2 ' $-25,9 \mathrm{~cm}(\max 60, \min 7)$ and $28,3 \mathrm{~cm}(\max 56, \min 6 \mathrm{~cm})$ for the plot 'Pine 3 '.

All the research areas were facing eastwards and the ground slope was $15-17^{\circ}$. All the species observed, originated from self-sowing, except beech located in the 'Pine 1 ' plot. Beech in that area originated partially from sowing by human.

Statistical analyses were performed using STATISTICA software. In all three areas, DBH values are coming to form a normal, right-skewed distribution (Shapiro-Wilk test).

Each research area was a $25 \times 25 \mathrm{~m}$ rectangle. Such area $\left(625 \mathrm{~m}^{2}\right)$ is appropriate for gap models (Bugmann 1994). Running 200 simulations for each research area is equivalent to analyzing an area of approximately 12,5 ha $(200 \times 0,0625)$.

Each research area was constructed using standard measuring tape to establish a rectangular coordinate system ( $\mathrm{X}$ axis along $\mathrm{E}-\mathrm{W}$ and $\mathrm{Y}$ axis along $\mathrm{N}-\mathrm{S}$ line). Each and every tree within such established research area was assigned a unique number and measure (DBH, height, crown radius, age). The position of every tree was also established at $5 \mathrm{~cm}$ accuracy and then marked on a map using orthogonal survey method. The age was established with the help of Pressler drill. The diameter at breast height was measured using a dedicated meter at 1,3 m over the ground level. The tree height was measured with Leiss BL8 height-meter. In order to verify leaf area index (LAI) calculations, three hemispherical photographs were taken per research 
Table 1. Characteristic of trees on research plot

\begin{tabular}{|c|c|c|c|c|c|c|c|c|c|c|c|}
\hline \multirow{2}{*}{ Plot } & \multirow{2}{*}{ Species } & \multicolumn{3}{|c|}{$D[\mathrm{~cm}]$} & \multicolumn{3}{|c|}{$H[\mathrm{~m}]$} & \multicolumn{3}{|c|}{ Age (years) } & \multirow{2}{*}{$N$} \\
\hline & & mean & $\min$ & $\max$ & mean & $\min$ & $\max$ & mean & $\min$ & $\max$ & \\
\hline 1 & Abies alba & 10,0 & 5,0 & 18,0 & 7,6 & 4,0 & 13,0 & 14,8 & 11,0 & 16,0 & 8 \\
\hline 1 & Fagus sylvatica & 8,3 & 6,0 & 14,0 & 5,4 & 4,0 & 9,0 & 15,4 & 12,0 & 20,0 & 7 \\
\hline 1 & Betula pendula & 20 & 20 & 20 & 16 & 16 & 16 & 26 & 26 & 26 & 1 \\
\hline 1 & Picea abies & 9,4 & 4,0 & 21,0 & 8,6 & 4,0 & 18,0 & 16,2 & 11,0 & 35,0 & 10 \\
\hline 1 & Pinus sylvestris & 24,4 & 5,0 & 65,0 & 18,0 & 5,0 & 39,0 & 67,5 & 10,0 & 148,0 & 35 \\
\hline 2 & Abies alba & 7,0 & 7,0 & 7,0 & 7,0 & 7,0 & 77,0 & 19,0 & 19,0 & 19,0 & 1 \\
\hline 2 & Fagus sylvatica & 7,0 & 5,0 & 8,0 & 5,2 & 4,0 & 6,0 & 14,0 & 4,0 & 6,0 & 5 \\
\hline 2 & Picea abies & 12,4 & 9,0 & 16,0 & 10,0 & 8,0 & 12,0 & 33,2 & 24,0 & 43,0 & 5 \\
\hline 2 & Pinus sylvestris & 25,9 & 7,0 & 60,0 & 14,9 & 5,0 & 29,0 & 68,9 & 19,0 & 160,0 & 37 \\
\hline 3 & Abies alba & 5,0 & 5,0 & 5,0 & 6,0 & 6,0 & 6,0 & 19,0 & 19,0 & 19,0 & 1 \\
\hline 3 & Fagus sylvatica & 7,0 & 5,0 & 8,0 & 5,2 & 4,0 & 6,0 & 14,0 & 10,0 & 16,0 & 5 \\
\hline 3 & Picea abies & 7,6 & 5,0 & 13,0 & 6,8 & 5,0 & 10,0 & 20,2 & 13,0 & 35,0 & 5 \\
\hline 3 & Pinus sylvestris & 28,3 & 6,0 & 56,0 & 16,1 & 7,0 & 28,0 & 75,4 & 19,0 & 149,0 & 39 \\
\hline
\end{tabular}

Designations: $D-$ d.b.h., $H$ - height, $N$ - number of trees

area (model FORKOME, SLR camera Canon EOS 5D 12MP, Sigma 8mm f/3,5 DG FISH EYE lens with $180^{\circ}$ viewing angle). The hemispherical photographs were analysed with the help of the Gap Light Analyzer software (Frazer et al. 2000). The software enabled measuring not only LAI, but also the absolute amount of direct and scattered light, structure of canopy openness, spatial variability of canopy foliage and biomass of the assimilation apparatus. Next, the obtained results were used to verify the FORKOME model input parameters (assimilation apparatus biomass). Selected data were stored in csv format (using Microsoft Excel spreadsheet) and supplied to the FORKOME model.

The FORKOME model is based upon the theory of forest ecosystems patch dynamics. It can be used to simulate forest association succession while taking into account the association characteristics (species composition, age, etc.), as well as the specificity of individual growth. The latter can be simulated as a function of both external (light intensity, ambient temperature, etc.) and internal (competition) ecological factors.

Based on appropriate equations, the model simulates reproduction, growth and death of trees every year
(Brzeziecki 1999; Kozak et al. 2012). For every species available in the model, specific death age has been assumed, e.g. 400 years for pine. The sets of parameters used in the model take into account the most important ecological and breeding properties of each species. Since the parameters reflect several properties and habitats of specie, they can vary to a certain degree. The FORKOME model is also capable of taking into account natural disasters, forest fires in particular (Kozak et al. 2012). In general, pine requires light for successful restoration (weak natural renewal under forest canopy and optimal on fire-opened spaces). The model allows simulating both types of restoration. It is possible to display the distribution of trees in the research areas as shown in Figure 1a, 1b, 1c. Simulation time was set to 100 years and simulation type to Monte Carlo (200 runs). Forecasts of biomass changes and the number of trees were made for all pine areas.

To analyze climate changes, the FORKOME model uses the method proposed by Kahn (1994) which has been used previously, e.g. in the SILVA hybrid model of forest dynamics (Pretzsch et al. 2002). Out of the factors considered by Kahn (1994), only the basic ones were 


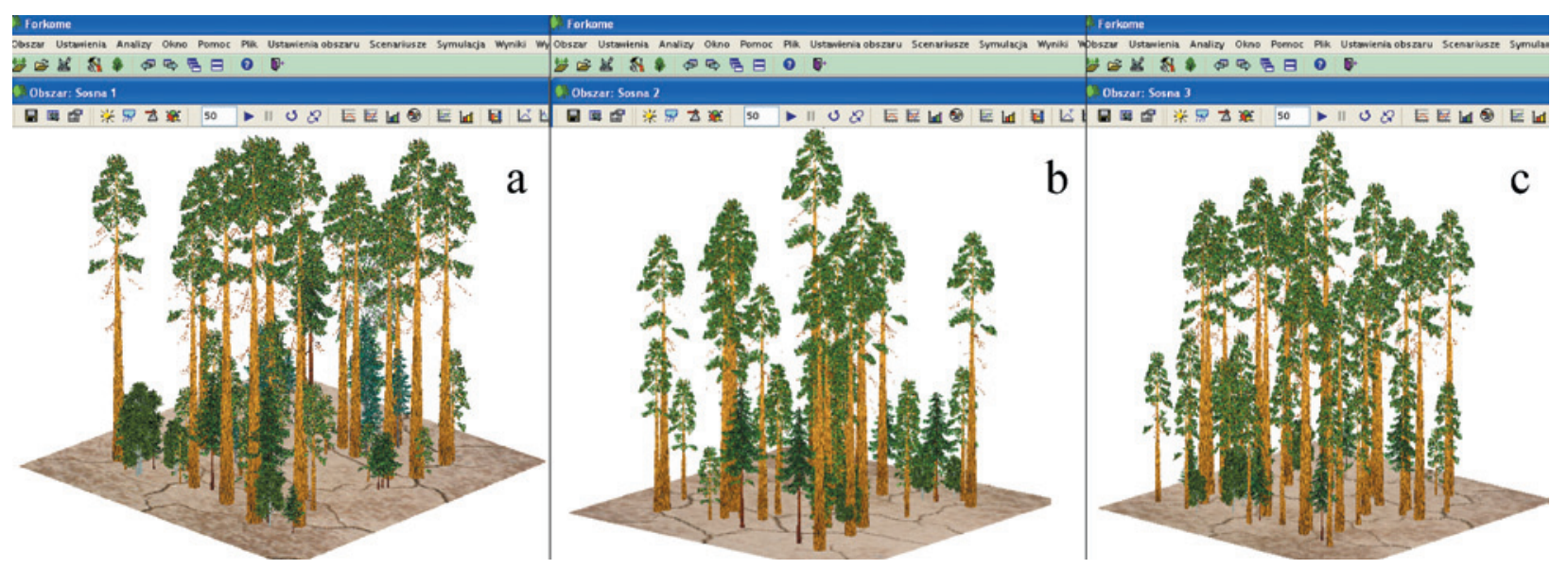

Figure 1. Beginning stage (3D visualization in FORKOME model) of plots in control scenario: a - 'Pine 1', b - 'Pine 2', c - 'Pine 3'

used in this study: annual temperature amplitude, mean vegetation period temperature, and vegetation period total precipitation.

The influence of climate changes (total effective temperatures and total annual precipitation) on the rate of pine replacement by other species (beech, fir, spruce, hornbeam) was also the subject of this study. To this end, 'temperature changes scenario' and 'precipitation changes scenario' tools were used. To assess the influence of temperature changes the following values were used:

the plot 'Pine 1': control - 1425 degree days, 'warmdry' and 'warm-humid' scenario - 1625 degree days, 'cold-dry' and 'cold-humid' scenario - 1225 degree days.

- The plot 'Pine 2': control - 1435 degree days, 'warm-dry' and 'warm-humid' scenario - 1635 degree days, 'cold-dry' and 'cold-humid' scenario - 1235 degree days.

- The plot 'Pine 3': control - 1440 degree days, 'warm-dry' and 'warm-humid' scenario - 1640 degree days, 'cold-dry' and 'cold-humid' scenario - 1240 degree days.

Similarly, to assess the influence of precipitation changes, the following values were used:

- The plot 'Pine 1': control - $718 \mathrm{~mm}$ (data from weather station in Zwierzyniec, Poland), 'warm-dry' and 'cold-dry' scenario - $618 \mathrm{~mm}$, 'warm-humid' and 'cold-humid' scenario - $818 \mathrm{~mm}$.

- The plot 'Pine 2': control - $713 \mathrm{~mm}$ (data from weather station in Rava-Rus'ka, Ukraine), 'warm-dry' and 'cold-dry' scenario - $613 \mathrm{~mm}$, 'warm-humid' and 'cold-humid' scenario $-813 \mathrm{~mm}$.
- The plot 'Pine 3': control - $645 \mathrm{~mm}$ (data from weather station in Lviv, Ukraine), 'warm-dry' and 'cold-dry' scenario - $545 \mathrm{~mm}$, 'warm-humid' and 'coldhumid' scenario $-745 \mathrm{~mm}$.

No climate change scenario $(\mathrm{kn})$ was used as control. Next, the following climate change scenarios are defined:

- warm-dry (wd): temperature increase by 200 degree days and decrease in precipitation by $100 \mathrm{~mm}$,

- warm-humid (wh): temperature increase by 200 degree days and increase in precipitation by $100 \mathrm{~mm}$,

- cold-dry (cd): temperature decrease by 200 degree days and decrease in precipitation by $100 \mathrm{~mm}$,

- cold-humid (ch): temperature decrease by 200 degree days and increase in precipitation by $100 \mathrm{~mm}$,

\section{Results}

Diagrams presenting results of prognosis of plots 'Pine 1', 'Pine 2', and 'Pine 3' are placed in the paper under the control scenario, as well as in 4 climate changes scenarios. Analyses of the aforementioned diagrams indicate that under the control scenario, (cs) pine biomass will increase during the period predicated at 56 (Fig. 2a) or 60 years (Fig. 3a, Fig. 4a). In 'Pine $1^{\prime}$, the area placed west, pine biomass will be $420 \mathrm{t} / \mathrm{ha}$, and in the other plots, i.e. 'Pine 2' and 'Pine 3', pine biomass will increase to 550 and $670 \mathrm{t} / \mathrm{ha}$. Decreasing tendency of pine biomass may be observed in almost all areas under the control scenario after the 60th year of the prognosis. However, inconsiderable increase of pine biomass occurs at the end of prognosis time (between 
Figure 2. Biomass total production, accumulation (a) and number of trees (b) of analysed species in the control scenario on the plot 'Pine 1'

Figure 3. Biomass total production, accumulation (a) and number of trees (b) of analysed species in the control scenario on the plot 'Pine 2'

Figure 4. Biomass total production, accumulation (a) and number of trees (b) of analysed species in the control scenario on the plot 'Pine 3'
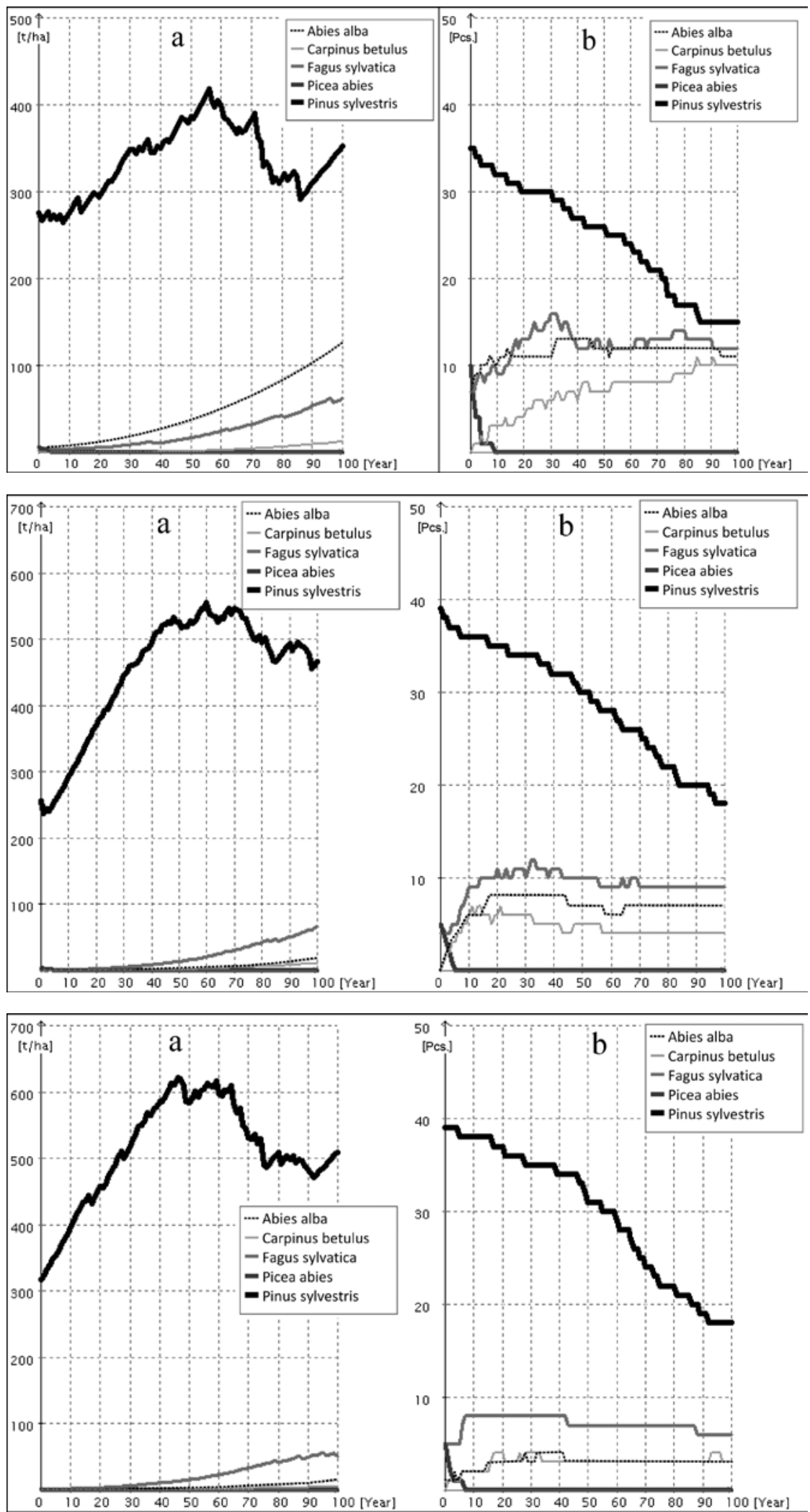


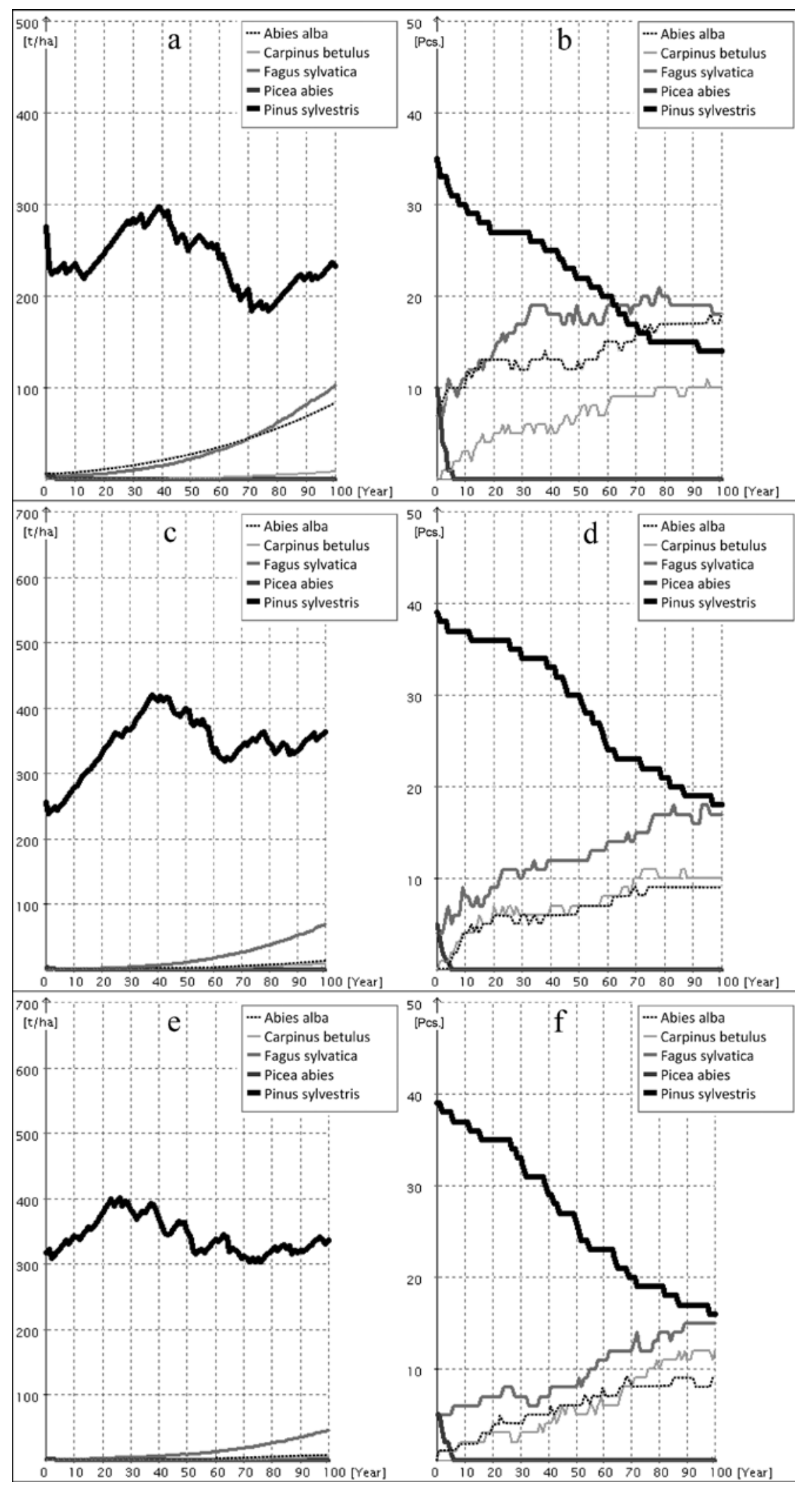

Figure 5. Biomass total production, accumulation (left) and number of trees (right) of analysed species in the warm dry climate scenario (wd) on the plots $(\mathrm{a}, \mathrm{b})$ 'Pine 1', (c, d) 'Pine 2', (e, f) 'Pine 3' 
Figure 6. Biomass total production, accumulation (left) and number of trees (right) of analysed species in the warm humid climate scenario (wh) on the plots $(\mathrm{a}, \mathrm{b})$ 'Pine 1', (c, d) 'Pine 2', (e, f) 'Pine 3'

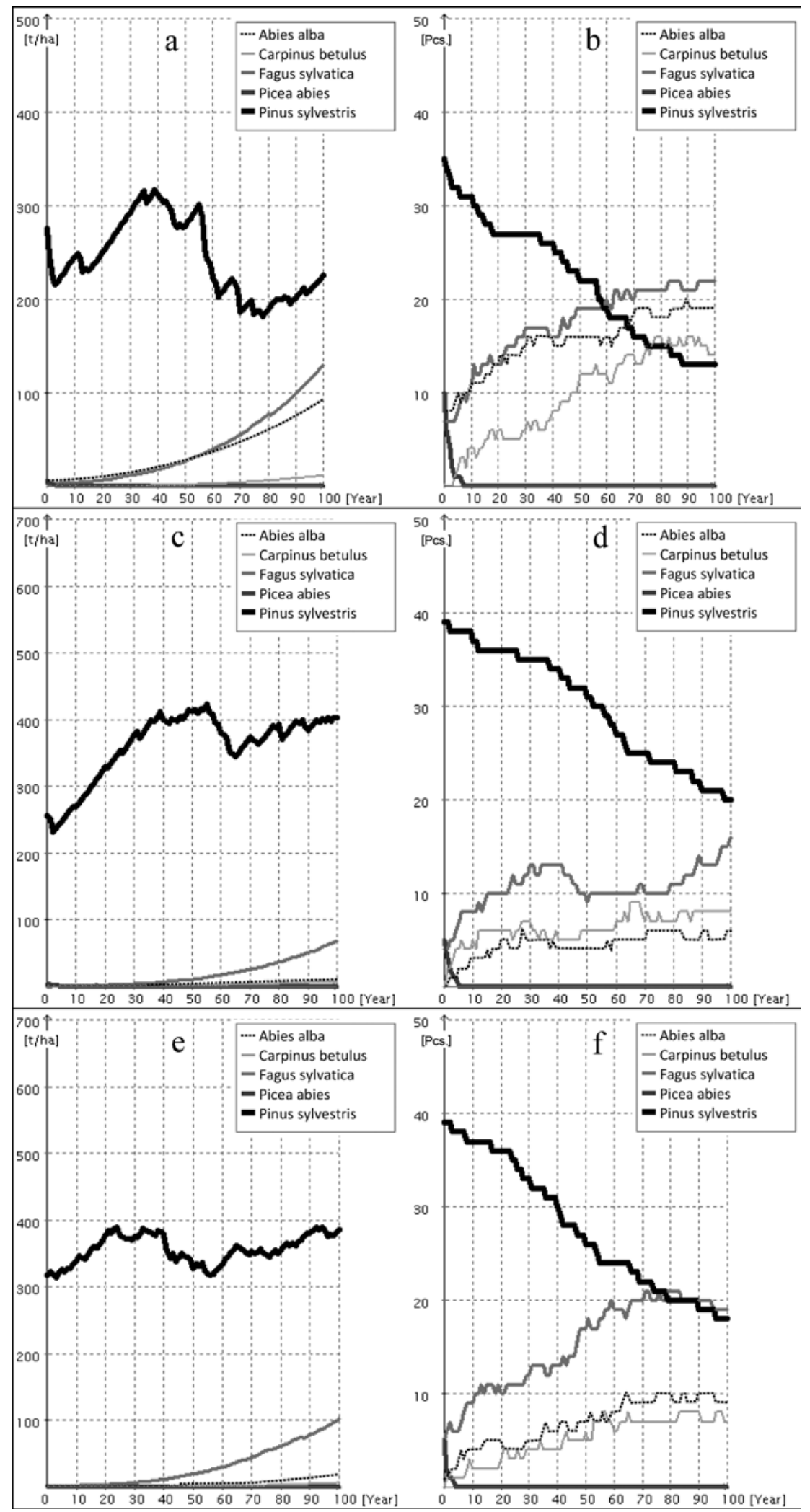




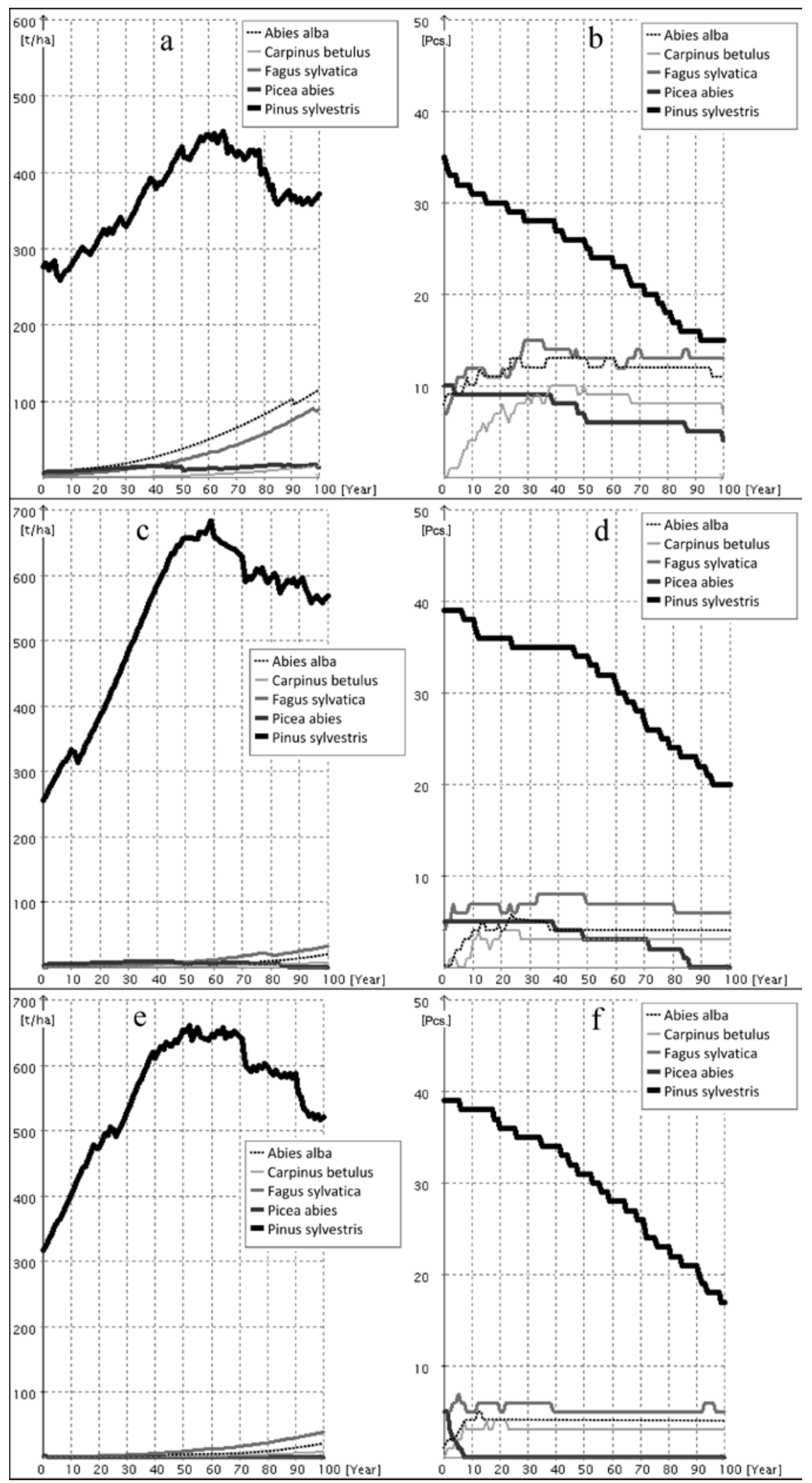

Figure 7. Biomass total production, accumulation (left) and number of trees (right) of analysed species in the cold dry climate scenario (cd) on the plots $(\mathrm{a}, \mathrm{b})$ 'Pine 1 ', $(\mathrm{c}, \mathrm{d})$ 'Pine 2', (e, f) 'Pine 3' 
Figure 8. Biomass total production, accumulation (left) and number of trees (right) of analysed species in the cold humid climate scenario (ch) on the plots $(\mathrm{a}, \mathrm{b})$ 'Pine 1', (c, d) 'Pine 2', (e, f) 'Pine 3'

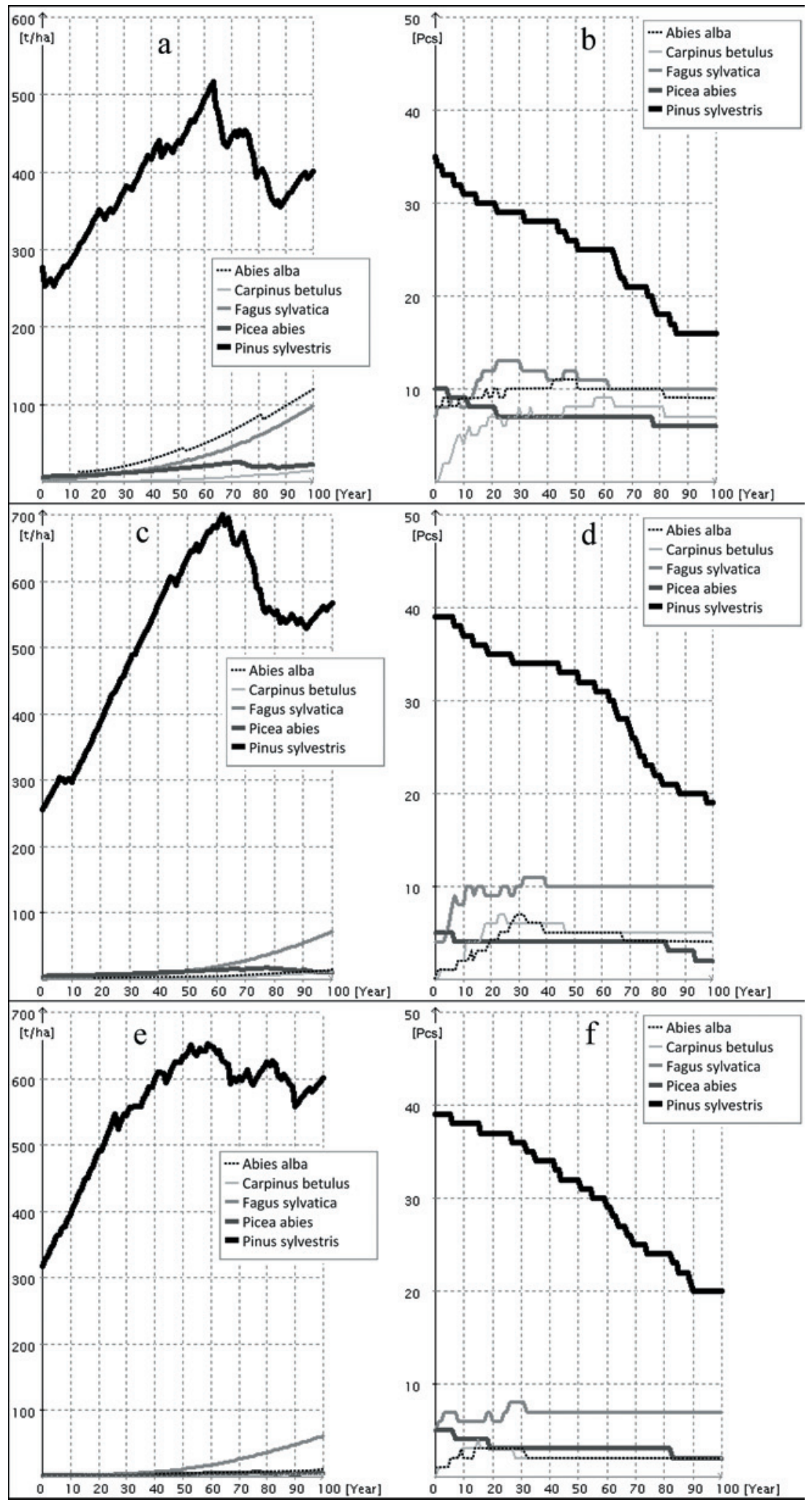


scenarios. Changing climate scenario, the cold dry climate scenario (cd) indicates that pine biomass will come to $450 \mathrm{t} / \mathrm{ha}$ in the plot 'Pine 1', and $690 \mathrm{t} / \mathrm{ha}$ and 670 t/ha in the plots 'Pine 2' and 'Pine 3'. Beech and fir biomass will decrease, but spruce biomass will increase. Regarding the number of trees, spruce will increase in comparison to the control, especially, under the plot 'Pine 1' (Fig. 7b) and under the plot 'Pine 2' (Fig. 7d). Number of beech trees will remain at a minimum level.

In the cold humid (ch) climate scenario, pine biomass will increase in comparison to the control. It will be even larger compared to the cold dry climate (cd) scenario. It will come to $520 \mathrm{t} / \mathrm{ha}$ in the plot 'Pine 1' (Fig. 8a), 700 t/ha in the plot 'Pine 2' (Fig. 8c), and $670 \mathrm{t} /$ ha in the plot 'Pine 3' (Fig. 8e). Regarding number of trees, spruce increase can be observed. Beech and fir individuals will remain at a low level.

\section{Discussion}

We carried out simulations with the FORKOME model in 3 research areas of $25 \times 25 \mathrm{~m}$ (1/16 ha) each. Therefore, within $625 \mathrm{~m}^{2}$ of the area, 200 used simulation sequences correspond with equilibrium landscape of 12,5 ha.

In other types of models, for instance the JABOWA model (Botkin et al. 1972), $10 \times 10 \mathrm{~m}$ areas were used with 100 simulations. The smallest area was 0,5 ha and was used in the FORSKA model (Leemans, Prentice 1987). Research carried out in Roztocze proved that it is relevant to use research area $625 \mathrm{~m}^{2}$ of size in patchwise models.

Results of studies carried out with the FORKOME model indicate that pine will not be dominated by other species during the period of the next 100 years. Studies presented in literature have corroborated the aforementioned thesis. For instance, it has been observed that pine in the area close to the South border of pine specie range, in Northeast Spain (MartinezVilalta et al. 2008), increased the sectional area by $84 \%$ during the 20th century. It has not been excluded that the trend relates to increasing of $\mathrm{CO}_{2}$ in the atmosphere.

Simulation of the dynamics of pine stands in Roztocze was based on research areas placed in pine stands where podzol soil dominates. This type of soil is usually overgrown by pine stands (for instance in Roztocze), while spontaneous combustion of the forest enable pine to restore (Kozak et al. 2012).

It is proved from computer simulations that the number of pine trees decreases continually - old trees whither, and canopy cover does not allow younger individuals to receive enough amount of light for growing. Diagrams indicate slow tree restoration (without a fire).

Other authors have often used the FORKOME model in computer simulations regarding different climate change scenarios (warm dry, warm humid, cold dry and cold humid) (Brzeziecki 1999). It has not only been a theoretical application, but also practical application, because it enables determining the directions of changes in the environment and then, defines proper management and protection strategies.

It is not easy to predict climate changes for a long period of time, because it is impossible to assume that climate will change only in one direction. That's why we carried out four simulation variants and results are convergent with the pine ecological requirements (Ellenberg 1986; Kahn 1994).

Pine is characterised by broadest ecological spectrum among all analysed species. It is important in particular in case of extreme temperatures and humid conditions in connection with weak podzol soil. Beech, fir, and spruce die as first in such conditions. Prognosis results done with the FORKOME model are relatively representative. Studies carried out in Roztocze National Park (Maciejewski 2009; Maciejewski 2011; Maciejewski, Szwagrzyk 2011), Rava-Rus'ka Landscape Reserve and (Cherniavskyi, Sawka 2004) and Yavorivskyi National Park (Horoszko, Homiuk 2011) can corroborate these results.

Studies with the FORKOME model give results which are convergent with results presented in literature (Maciejewski 2009; Maciejewski 2011; Maciejewski, Szwagrzyk 2011; Horoszko, Homiuk 2011). During the period of 100 years, the FORKOME model predicts that pine stands will remain, even in the warm dry climate scenario (wd), and what is corroborated by the pine classification, as the specie is relatively adapted for drought (Ellenberg 1986). It predicts that changes in species' structure of pine stands will occur by increasing number of beech, fit, and hornbeam in warming climate scenarios. It is worth mentioning that warming climate process is one of hypothesis (Fabijanowski, Jaworski 1996) to explain that phenomenon. We made an assumption that climate conditions for analysed pine stand areas in Roztocze in the FORKOME model are compatible with conditions in the research areas. These assumptions proved to be propitious for pine.

Prediction research on stands development, in regard to climate change conditions, is a significant type 
of scientific research. The FORKOME model is a good enabler to obtain results that prove the thesis assumed in our paper. Results obtained from the prediction research correspond to results obtained from field works and phenomenon described in literature. The FORKOME model proved to be efficient tools adjusted to the research regarding dependences and changes in species structure of forest stands, species biomass, and number of trees. It is possible to devise methods in the model to analyze many parameters of forest stands conditions at the same time what allows obtaining precise results. The FORKOME model enables analyzing the dynamics of forest stands in regard to climate change conditions during any period of time, chosen by the user of the model.

\section{Conclusions}

Computer simulations presented in the paper indicate that pine will be basic species regardless of climate changes, and in case of worse soil and water conditions, it will be the main specie of forest stands grown on podzol soil in Polish and Ukrainian parts of Roztocze. Pine will not become less competitive in Roztocze in comparison to beech or fir, especially in stands grown on weak podzol soil. Beech, fir, and spruce grown in these stands will be always second-rated and considered admixture species.

In pine stands in Roztocze, pine will maintain its domination regarding biomass in the control scenario, warm dry climate scenario (wd), warm humid climate scenario (wh), cold dry climate scenario (cd), and cold humid climate scenario (ch) in the period of the next 100 years. Pine has optimal growing conditions in Polish and Ukrainian parts of Roztocze.

Thanks to adequate tools (climate change scenarios), the FORKOME model is adjusted to prediction research regarding forest studies and it enables verifying assumed hypothesis. Results obtained from prediction research made in the FORKOME model proved the usefulness of the model for simulation of dynamics of pine stands in Polish and Ukrainian parts of Roztocze.

\section{Acknowledgements}

We would like to thank all employees of Roztoczanski National Park in Poland, Rava-Rus'ka Landscape Reserve and Yavorivskyi National Park in Ukraine for their help, as well as Ministry of Science and Higher Education for financing the research project (Project No. NN 309 014638).

\section{References}

Botkin D. B., Janak J. G., Wallis J. R. 1972. Some ecological consequences of a computer model of forest growth. Journal of Ecology, 60: 849-872.

Brzeziecki B. 1999. Ekologiczny model drzewostanu: zasady konstrukcji, parametryzacji i przykłady zastosowań. Warszawa, Fundacja Rozwoju SGGW, p. 115. ISBN 8387660-65-5.

Brzeziecki B., Zajączkowski J. 2006. FORLAS 2.0. Program komputerowy i podręcznik użytkownika [FORLAS: Ecological model of stand development]. SGGW, Katedra Hodowli Lasu, p. 38.

Bugmann H. 1994. On the ecology of mountainous forests in a changing climate: a simulation study. $\mathrm{Ph}$. D. thesis no. 10638, Switzerland, Swiss Federal Institute of Technology Zurich.

Cherniavskyi M. W., Sawka H. S. 2004. Funkcionalne zonuwannja Regionalnoho Landszaftnoho Parku 'Raws'ke Roztochia', in: Naukowij Wisnik Ukr DLTU, 14, 8: 241-252. Lviv, Ukrainskyj Djerżawnyj Lisotechnicznyj Uniwersytet. ISBN 5-7763-2435-1.

Ellenberg H. 1986. Vegetation Mitteleuropas mit den Alpen aus okologischer Sicht. Stuttgart, Ulmer, 989 p.

Horoszko M. P., Homiuk P. H. 2011. Znaczennja typologicznoho profilu A. Piasec'koho dla ocinky zmin typiw lisu w umowach Ukraińskoho Roztoczja. Naukowij Wisnik Ukr DLTU, 21, 11: 16-20. Lviv, Ukrainskyj Djerżawnyj Lisotechnicznyj Uniwersytet. ISBN 5-7763-2435-1.

Izdebski K., Czarnecka B., Grądziel T., Lorens B., Popiołek Z. 1992. Zbiorowiska roślinne Roztoczańskiego Parku Narodowego na tle warunków siedliskowych. Lublin, Wydawnictwo Uniwersytetu Marii Curie-Skłodowskiej.

Fabijanowski J., Jaworski A. 1996. Kierunki postępowania hodowlanego w lasach karpackich wobec zmieniających się warunków środowiska [Guidelines of silvicultural treatments in Carpathian forests facing changing environmental conditions]. Sylwan, 8: 75-97. 
Frazer G.W., Canham C.D., Lertzman K.P. 2000. Gap Light Analyzer (GLA), Version 2.0, Image processing software to analyze true-colour, hemispherical canopy photographs. Bulletin Ecological Society of America, 81: 191-197.

Kahn M. 1994. Modellierung der Hohenentwicklung ausgewahlter Baumarten in Abhangigkeit vom Standort. Forstliche Forschungsberichte Munchen, 141: 1-204.

Kozak I., Mikusiński G, Stępień A., Kozak H., Frąk R. 2012. Modelling forest dynamics in a nature reserve: a case study from south-central Sweden. Journal of Forest Science, 58, 10: 436-445.

Leemans R., Prentice I. C. 1987. Description and simulation of tree layer composition and size distribution in a primeval Picea-Pinus forest. Vegetatio, 69: 147-156.

Maciejewski Z. 2009. Stabilność a dynamika naturalnych ekosystemów leśnych w świetle 35-letnich badań obszarów chronionych Roztoczańskiego Parku Narodowego, in: Roztoczańskie Spotkania. Wykłady otwarte $\mathrm{z}$ lat 2006-2009. Zwierzyniec, Ośrodek Edukacyjno-Muzealny Roztoczańskiego Parku Narodowego, 6: 92-105.
Maciejewski Z. 2011Spontaneous regeneration of a Carpathian beech forest in planted pine stands on the Roztocze Highlands (Roztocze National Park, south-east Poland). Polish Journal of Ecology, 59 (2): 285-297.

Maciejewski Z., Szwagrzyk J. 2011. Long-term changes in stand composition of natural forest stands on the Roztocze Highlands. Polish Journal of Ecology, 59 (3): 535-549.

Martinez-Vilalta J., Lopez B.C., Adell N., Badiella L., Ninyerola M. 2008. Twentieth century increase of Scots pine radial growth in NE Spain shows strong climate interactions. Global Change Biology, 14: 2868-2881.

Pretzsch H., Biber P., Durskỳ J. 2002. The single tree based stand simulator SILVA.

Construction, application and evaluation. Forest Ecology and Management, 162: 3-21.

Shugart H. H. 1984. Theory of forest dynamics. New York, Springer. ISBN 0-387-96000-7.

Translated by: Martyna Olszowska 